\title{
Hyperthermia does not protect Kona stock Penaeus vannamei against infection by a Taura syndrome virus isolate from Belize
}

\author{
Isabelle Côté ${ }^{1,2, *}$, Donald V. Lightner ${ }^{1}$ \\ ${ }^{1}$ Aquaculture Pathology Laboratory, Department of Veterinary Science and Microbiology, University of Arizona, \\ 1117 East Lowell Street, Tucson, Arizona 85721, USA
}

${ }^{2}$ Present address: Laboratoire d'expertises enpathologie animale du Québec, Ministère de l'agriculture, des pêcheries et de l'alimentation du Québec, 2700 rue Einstein, Sainte Foy, Québec G1P 3W8, Canada

\begin{abstract}
This study evaluated the susceptibility of Penaeus vannamei, Kona stock-line, to infection by an isolate of Taura syndrome virus from Belize (TSV-BZ) under hyperthermic conditions $\left(32^{\circ} \mathrm{C}\right)$. Shrimp exposed to the reference Hawaii-94 isolate of TSV (TSV-HI) showed resistance to infection at $32^{\circ} \mathrm{C}$ as demonstrated by the absence of mortality, histopathological lesions and decreased viral load by qPCR. However, at $32^{\circ} \mathrm{C}$, shrimp were fully susceptible to the disease caused by TSV-BZ, exhibiting high mortality, severe histopathological lesions and increased viral load. This susceptibility of shrimp to TSV-BZ infection under hyperthermic conditions was independent of the route of infection (injection vs. per os) and the salinity of the water (11 vs. 28). TSV-BZ might be a temperature-permissible mutant of TSV.
\end{abstract}

KEY WORDS: Belize variant $\cdot$ Taura syndrome virus $\cdot$ Immune response $\cdot$ Hyperthemia $\cdot$ Penaeus vannamei $\cdot$ Shrimp

\section{INTRODUCTION}

Taura syndrome virus (TSV) is a shrimp virus and a member of the Discistroviridae family (Hasson et al. 1995, Mayo \& Ball 2006). Many isolates of the virus have been characterized, notably the Hawaii-94 reference strain (TSV-HI) and more recently the 2002 isolate from Belize (TSV-BZ) (Erickson et al. 2005).

Montgomery-Brock \& Shimojo (2003) showed that hyperthermic water temperature $\left(32^{\circ} \mathrm{C}\right)$ was associated with higher survival of shrimp exposed per os to TSV-HI. In the present study, we report the results of experiments that showed Kona stock $P$. vannamei exposed to TSV-BZ presented unexpectedly high mortalities under hyperthermic conditions.

\section{MATERIALS AND METHODS}

Shrimp stock. The Oceanic Institute in Hawaii provided specific pathogen free (SPF) Penaeus vannamei, Kona stock-line. Shrimp weighed between 1 and $4 \mathrm{~g}$.

Bioassay. For all bioassays, $90 \mathrm{l}$ aquaria fitted with a biological filter were used as described in White et al. (2002). Artifical seawater was used (Marine Enterprises International). All experiments were run at salinity 28 except for one study where salinity 11 was used. Electric immersion heaters were used to maintain hyperthermic conditions at $32^{\circ} \mathrm{C}$, while room temperature (RT) tanks varied between 25 and $28^{\circ} \mathrm{C}$. The water temperature was monitored twice daily with a hand-held thermometer. Shrimp were fed pelleted 
Rangen feed (Buhl, ID; 35\% protein) ad libitum. The bioassays were performed once and terminated 36 to $72 \mathrm{~h}$ following the last mortality in the positive control tanks.

Bioassay 1: infection with TSV-BZ via 2 routes of exposure at $32^{\circ} \mathbf{C}$. The set up of the experiment for both routes of exposure was as follows: 2 exposed tanks at $32^{\circ} \mathrm{C}, 1$ exposed tank at RT and 1 non-exposed tank at $32^{\circ} \mathrm{C}$. The shrimp density was 10 per tank (11 shrimp for one of the TSV-injected hyperthermic tanks). Shrimp exposed by injection received $50 \mu \mathrm{l}$ in the second abdominal segment of a 1:10 dilution in $2 \%$ saline of TSV-BZ infected tissue homogenate. The negative control shrimp were injected with $50 \mu \mathrm{l}$ of SPF tissue homogenate diluted $1: 10$ in $2 \%$ saline. The shrimp infected by the oral route were fed $10 \%$ of their body weight (BW) of TSV-BZ infected minced tissues on Days 1 and 2. Negative control shrimp for the feeding experiment were fed Rangen feed only.

Throughout the assay, moribund shrimp were fixed with Davidson's AFA for examination by histopathology (Bell \& Lightner 1988). The pleopods of these shrimp were fixed in $95 \%$ ethanol prior to RNA extraction with a High Pure RNA Tissue kit (Roche) according to the manufacturer's recommendation (standard reaction). The virus was quantified by qRT-PCR using a Taq Man probe and normalized to total RNA (Tang et al. 2004). At the end of the assay, survivors were fixed for examination by histology for signs of infection by TSV.

Bioassay 2: per os infection with TSV-BZ at $32^{\circ} \mathrm{C}$ and salinity 11. For this experiment, all tanks were hyperthermic with 2 TSV-exposed tanks at $11 \mathrm{ppt}$ ( $\mathrm{n}=11$ each), 1 TSV-exposed tank at $28 \mathrm{ppt}(\mathrm{n}=10)$ and 1 non-exposed tank at 11 ppt $(\mathrm{n}=10)$. The salinity of the water was measured twice daily with a hand-held refractometer. At the end of the assay, survivors were examined by histology for signs of infection by TSV.

Biossay 3: infection with TSV-HI at $32^{\circ} \mathrm{C}$. The design of this experiment was 2 TSV-exposed tanks at $32^{\circ} \mathrm{C}(\mathrm{n}=10$ each), $1 \mathrm{TSV}$-exposed tank at RT ( $\mathrm{n}=$ 9) and 1 non-exposed tank at $32^{\circ} \mathrm{C}(\mathrm{n}=9)$. The injection was performed as for Bioassay 1. During the assay, 1 moribund shrimp from the RT TSVexposed tank was fixed for histopathology. Two survivors per tank were fixed and processed for histopathological analysis and in situ hybridization (ISH) (Mari et al. 1998).

Bioassay 4: time-course of the viral load with infection with TSV-HI at $32^{\circ} \mathrm{C}$. This experiment consisted of 2 treatment tanks at RT and 2 treatment tanks at $32^{\circ} \mathrm{C}$. The shrimp density in each treatment tank was 25. Two negative control tanks, each with 5 shrimp injected with $2 \%$ saline, were kept at both RT and high temperature. At Time 0, the treatment shrimp were injected with TSV-HI. Each exposed tank was sampled ( $\mathrm{n}=4$ to 5 ) every $12 \mathrm{~h}$ post-infection (pi), with 9 shrimp sampled at 12,24 and $36 \mathrm{~h}$ for the $32^{\circ} \mathrm{C}$ treatment, 10 shrimp at 12, 24 and $36 \mathrm{~h}$ for the RT treatment and 10 shrimp for both the $32^{\circ} \mathrm{C}$ and RT treatment at the $48 \mathrm{~h}$ time point. At the selected time-points, shrimp were randomly selected and killed. Their pleopods were excised and preserved in ethanol until used for RNA extraction and Real-time qRT-PCR. Histology was performed on 5 shrimp per infected tank (10 shrimp per treatment) and 2 shrimp per negative control tank collected at $48 \mathrm{~h}$ pi.

\section{RESULTS}

\section{Bioassay 1: infection with TSV-BZ via 2 routes of exposure at $32^{\circ} \mathrm{C}$}

During the assay, 5 hyperthermic TSV-injected, 1 RT TSV-injected, 4 hyperthermic TSV-fed and 2 RT TSV-fed shrimp were sampled. Shrimp presented low survival when challenged with TSV-BZ by either per os $(20 \%)$ (data not shown) or injection-mediated $(21 \%)$ exposure at $32^{\circ} \mathrm{C}$ (Fig. 1). Negative control shrimp kept at this temperature did not present any mortality and had no lesions indicative of TSV by histology. All moribund shrimp collected throughout this assay presented lesions characteristic of the acute or transitional phase of TSV. In these shrimp, viral copy number, varied from $1.87 \times 10^{6}$ to $2.78 \times 10^{8}$. All TSVexposed survivors had severe lymphoid organ spheroids (LOS) suggestive of a chronic TSV infection (Hasson et al. 1995). No other signs of pathology were found in these shrimp.

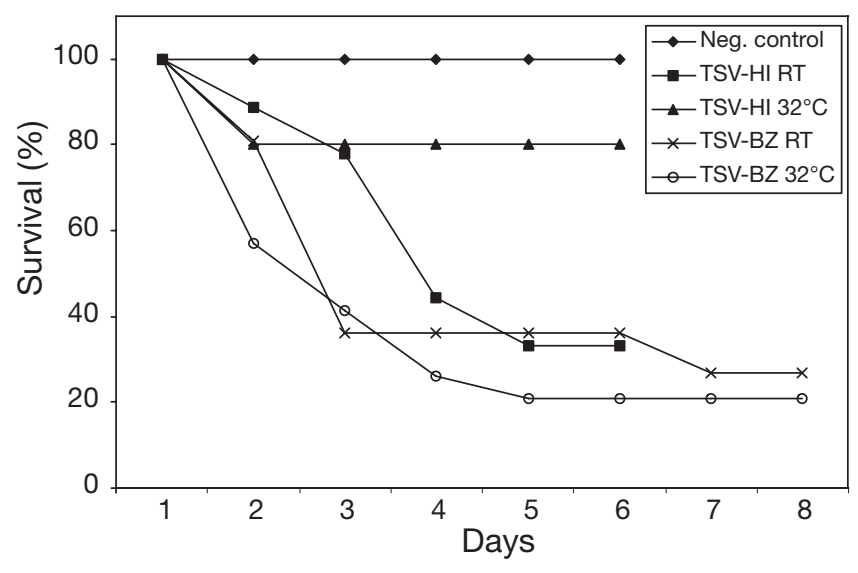

Fig. 1. Penaeus vannamei. Survival of shrimp injected with TSV-BZ or TSV-HI under hyperthermic conditions or at room temperature $\left(\mathrm{RT}, 25\right.$ to $\left.28^{\circ} \mathrm{C}\right)$ 


\section{Bioassay 2: per os infection with TSV-BZ at $32^{\circ} \mathrm{C}$ and salinity 11}

During the challenge 9 moribund shrimp from the low salinity tanks were fixed for examination by histopathology. Only dead autolyzed shrimp unsuitable for histologic analysis were found in the high salinity exposed tank. The average survival in the 2 TSV-BZ infected tanks at salinity 11 was $9 \%$. The tank at high salinity (28) had a survival of $30 \%$. All moribund shrimp sampled throughout the bioassay had lesions suggestive of acute or transitional TSV infection. All exposed survivors sampled at the end of the bioassay presented severe LOS suggestive of a chronic TSV infection. Non-exposed shrimp were normal upon histological examination and had $100 \%$ survival.

\section{Biossay 3: infection with TSV-HI at $32^{\circ} \mathrm{C}$}

Shrimp exposed to TSV-HI at $32^{\circ} \mathrm{C}$ presented higher survival $(80 \%)$ compared with exposed shrimp kept at RT (33\% survival) (Fig. 1). Upon histological examination, 1 shrimp from the positive control group fixed $3 \mathrm{~d}$ after the start of the challenge had lesions typical of acute TSV infection. The other exposed shrimp from this assay were found dead and were unsuitable for histological analysis. LOS were observed in the 2 survivors from the positive control and at a low to moderate grade in 2 out of 4 examined shrimp from the tanks at $32^{\circ} \mathrm{C}$. The LOS from infected shrimp kept at high temperature were poorly organized and negative for TSV by ISH.

\section{Bioassay 4: time-course of the viral load with infec- tion with TSV-HI at $32^{\circ} \mathrm{C}$}

There was a large variation in viral copy number $\mathrm{ng}^{-1}$ RNA amongst shrimp within each treatment (Table 1). Viral copies in the low temperature treat-

Table 1. Penaeus vannamei. Lesions, lymphoid organ spheroids (LOS) and maximal viral loads as determined by qRTPCR following exposure by injection to TSV-HI or TSV-BZ at 2 temperatures. Shrimp challenged with the TSV-HI genotype at $32^{\circ} \mathrm{C}$ presented $10000 \times$ fewer viral copies than did shrimp challenged at room temperature (RT) $\left(25\right.$ to $28^{\circ} \mathrm{C}$ )

\begin{tabular}{|lccccccc|}
\hline \multirow{2}{*}{ Isolate } & \multicolumn{3}{c}{ Acute lesions } & \multicolumn{3}{c|}{ LOS } & \multicolumn{3}{c|}{ Viral load (max.) } \\
& $\mathrm{RT}$ & $32^{\circ} \mathrm{C}$ & $\mathrm{RT}$ & $32^{\circ} \mathrm{C}$ & $\mathrm{RT}$ & $32^{\circ} \mathrm{C}$ \\
\hline TSV-BZ & + & + & + & + & $10^{8}$ & $10^{8}$ \\
TSV-HI & + & - & + & ${ }^{*}$ a & & $10^{6}$ & $10^{2}$ \\
a Atypical LOS & & & & & & & \\
\end{tabular}

ments were consistently higher compared to the high temperature treatments. Shrimp exposed at $32^{\circ} \mathrm{C}$ presented low titers that decreased following challenge. TSV was not detected by real-time qRT-PCR in shrimp from the negative control tanks. Histopathology results from TSV-HI challenged shrimp showed low levels of early acute phase TSV lesions in 6 out of 10 shrimp under low temperature conditions and none of the shrimp under hyperthermic conditions (number examined $=10$ ).

\section{DISCUSSION}

Shrimp exposed to TSV-BZ presented high mortality at $32^{\circ} \mathrm{C}$, independent of the route of exposure (per os or injection) and the salinity of the water (11 vs. $28 \mathrm{ppt}$ ). TSV-BZ infected shrimp had severe lesions typical of TSV associated with high viral copy number that indicate the replication of the virus at the higher temperature.

Shrimp challenged with TSV-HI at $32^{\circ} \mathrm{C}$ presented lower mortalities compared to shrimp kept at RT. The hyperthermic shrimp did not show sign of TSV-HI infection throughout the challenge. They were also free of typical TSV lesions by histopathology and presented very low viral copy number. This confirms that shrimp are protected against TSV-HI infection at $32^{\circ} \mathrm{C}$ under the conditions examined. This infection pattern is consistent with the behavior of other shrimp viruses. Hyperthermia has been shown to reduce shrimp susceptibility to viral infections such as white spot syndrome virus (Vidal et al. 2001, Granja et al. 2003) and infectious hypodermal and hematopoietic virus (D. Montgomery-Brock et al. 2007).

TSV-BZ might be a temperature-permissible mutant of TSV. Temperature-sensitive mutants, sometimes varying in as little as one nucleotide, are known to have different permissible temperatures. A singlenucleotide change in a capsid protein of poliovirus was sufficient to prevent the maturation of the virus at the non-permissive higher temperature (Compton et al. 1990). Temperature-sensitive RNA polymerase mutants of the foot-and-mouth disease virus (FMDV, a picornaviridae) have been described (Lowe et al. 1981). The mutants were the result of a single-basepair change in the gene encoding the RNA polymerase. The partial blockage of FMDV at higher temperature has long been recognized (Sharpe 1958).

In view of these results, we conclude that infection with TSV-BZ causes mortality under hyperthermic $\left(32^{\circ} \mathrm{C}\right)$ conditions in Kona stock Penaeus vannamei, independent of the route of exposure and the salinity (11 and $28 \mathrm{ppt}$ ), and that TSV-BZ may be a temperature-permissible mutant of TSV. 
Acknowledgements. Grant support for this study was from the United States Marine Shrimp Farming Consortium under Grant No. 2004-38808-02142 from the Cooperative State Research, Education and Extension Service, US Department of Agriculture, and a scholarship from the National Fisheries Institute. I.C. is thankful to B. White and R. Redman for technical assistance and to B. T. Poulos, who reviewed this manuscript.

\section{LITERATURE CITED}

Bell TA, Lightner DV (1988) A handbook of normal penaeid shrimp histology. World Aquaculture Society, Baton Rouge, LA

Compton SR, Nelsen B, Kirkegaard K (1990) Temperaturesensitive poliovirus mutant fails to cleave VP0 and accumulates provirions. J Virol 64:4067-4075

> Erickson HS, Poulos BT, Tang KFJ, Bradley-Dunlop D, Lightner DV (2005) Taura syndrome virus from Belize represents a unique variant. Dis Aquat Org 64:91-98

Granja CB, Aranguren LF, Vidal OM, Aragón L, Salazar M (2003) Does hyperthermia increase apoptosis in white spot syndrome virus (WSSV)-infected Litopenaeus vannamei? Dis Aquat Org 54:73-78

Hasson KW, Lightner DV, Poulos BT, Redman RM, White BL, Brock JA, Bonami JR (1995) Taura syndrome in Penaeus vannamei: demonstration of a viral etiology. Dis Aquat Org 23:115-126

Lowe PA, King AMQ, McCahon D, Brown F, Newman JWI

Editorial responsibility: Ken Hasson,

College Station, Texas, USA
(1981) Temperature-sensitive RNA polymerase mutants of a picornavirus. Proc Natl Acad Sci USA 78:4448-4452

> Mari J, Bonami JR, Lightner DV (1998) Taura syndrome of penaeid shrimp: cloning of viral genome fragments and development of specific gene probes. Dis Aquat Org 33: $11-17$

> Mayo MA, Ball LA (2006) ICTV in San Francisco: a report from the Plenary Session. Arch Virol 151:413-422

Montgomery-Brock D, Shimojo RY (2003) Increased water temperature improves survival of TSV-exposed shrimp. Global Aquacult Advocate August: 14-15

Montgomery-Brock D, Tacon AGJ, Poulos P, Lightner DV (2007) Reduced replication of infectious hypodermal and hematopoietic necrosis virus (IHHNV) in Litopenaeus vannamei held in warm water. Aquaculture 265:41-48

Sharpe HS (1958) Effect of temperature on the multiplication of foot-and-mouth disease virus in suspensions of kidney cells of the pig. Nature 182:1803-1805

Tang KFJ, Wang J, Lightner DV (2004) Quantitation of Taura syndrome virus by real-time RT-PCR with a TaqMan assay. J Virol Methods 115:109-114

Vidal OM, Granja CB, Aranguren F (2001) A profound effect of hyperthermia on survival of Litopenaeus vannamei juveniles infected with white spot syndrome virus. J World Aquacult Soc 32:364-372

White BL, Schofield PJ, Poulos BT, Lightner DV (2002) A laboratory challenge method for estimating Taura syndrome virus resistance in selected lines of Pacific white shrimp Litopenaeus vannamei. J World Aquacult Soc 33:341-348

Submitted: April 28, 2009; Accepted: August 13, 2009

Proofs received from author(s): January 11, 2010 